\title{
Review Article \\ Interaction between Biological Nitrogen Removal Processes and Operating Parameters: A Review
}

\author{
M. S. I. Mozumder*, M. D. Hossain \\ Department of Chemical Engineering and Polymer Science, Shahjalal University of Science and \\ Technology, Sylhet-3114, Bangladesh
}

Received 24 March 2020, accepted in final revised form 1 June 2020

\begin{abstract}
Nitrogen, mostly in the form of ammonia or nitrate containing wastewater deteriorated the water quality which simultaneously affects environment, plants, animals and human life. A number of researchers nowadays are conducting research to find out efficient and cost effective nitrogen removal technique along with optimum operating parameters. It is very important to uncover the optimum range of each parameter. In this study, it was winnowed to elicit the optimum operating ranges of dissolved oxygen concentration, temperature, $\mathrm{pH}$, free ammonia concentration, nitrate concentration and culture medium. The nitrogen removal techniques were compared, evaluated considering advantages and disadvantages of them. Partial nitrification combined with anaerobic ammonium oxidation was found most prospective nitrogen removal technique for wastewater treatment compare to other techniques (conventional nitrification-denitrification over nitrate/nitrite, anammox, SND etc.) due to less oxygen consumption $(62.5 \%$ less $)$, less sludge production, no carbon requirement, single reactor used and energy efficiency. SND process was more economical due to faster consumption of ammonia, nitrite and nitrate. There was various culture mediums which had a favorable or detrimental effect on specific nitrogen removal processes. However for desired bacteria culture for specific application, suitable culture medium needs to be selected considering the optimal operating parameters for microbial growth.
\end{abstract}

Keywords: Nitrification; Denitrification; Anammox; Nitrogen removal.

(c) 2020 JSR Publications. ISSN: 2070-0237 (Print); 2070-0245 (Online). All rights reserved. doi: http://dx.doi.org/10.3329/jsr.v12i4.46092

J. Sci. Res. 12 (4), 757-774 (2020)

\section{Introduction}

Industrial, agricultural and household effluents generate nitrogen containing wastewater where nitrogen stays as ammonium $\left(\mathrm{NH}_{4}{ }^{+}\right)$or nitrate $\left(\mathrm{NO}_{3}{ }^{-}\right)$. High nitrogen containing wastewater is originated from landfill leachate, industrial processes, compost and biodigester supernatants; the disposal of such wastewater damages the environment. Dissolved ammonium disposal is the prime factor for the eutrophication of aquatic

${ }^{*}$ Corresponding author: $\underline{\text { salatul-cep@ } \text { sust.edu }}$ 
system. So, nitrogen removal from wastewater has become a serious concern to discharge wastewater containing nitrogen within permissible limit. With increasingly stringent environmental regulations to build sustainable environment, advanced and cost-effective nitrogen removal technique is required.

Wastewater treatment plants are using conventional biological nitrificationdenitrification over nitrate to remove nitrogen. Many researchers are continually working to uncover more efficient, cost-effective, sustainable and environmentally friendly nitrogen removal processes. Various nitrogen removal processes have already been proposed based on the variety of process configurations; such as SHARON (Sustainable High Rate Ammonium Removal Over Nitrate), CANON (Completely Autotrophic Nitrogen Removal Over Nitrite), OLAND (Oxygen-Limited Autotrophic NitrificationDenitrification), DEMON ( $\mathrm{pH}$ Controlled Deammonification), Partial NitritationAnammox, Deammonification etc. [1-3].

Although partial nitritation-anammox process is an autotrophic process, up to $50 \%$ heterotrophic biomass in biofilms was grown on microbial decay products [4]. Heterotrophic growth reduced nitrate accumulation by utilizing organic substrate in both aerobic and anoxic conditions and produces carbon dioxide which ultimately decreases the $\mathrm{pH}$ of the system. Therefore, heterotrophic activity was an important factor that affects the overall nitrogen removal efficiency. Combined partial nitritation-anammox process, completely autotrophic process, can perform either in one or two stages reactor.

Various process parameters determined the efficiency of nitrification-denitrification; for instance, dissolved oxygen was a key factor for both heterotrophic and autotrophic nitrogen removal [5]. The level of oxygen should be low enough to establish partial nitritation/nitrification, but not to inhibit anaerobic denitrification. Organic load, expressed as COD to nitrogen ratio, was another critical parameter that had a large effect on nitrogen removal activity particularly in heterotrophic denitrification [6].

One of the recent review showed that COD removal efficiency was varied from $50 \%$ to $90 \%$ using biofilm reactor. They found a wide range of operating parameters; dissolved oxygen was from 0.2 to $6.5 \mathrm{mg} / \mathrm{L}$ and temperature range from 15 to $35{ }^{\circ} \mathrm{C}$. The ratio of nitrate to ammonium conversion was from 0.2 to 90 and $\mathrm{N}_{2}$ conversion was from 0 to $8.5 \mathrm{mg}$ [7].

In this study, detailed literatures were examined to evaluate the principle pathways involved in biological nitrogen removal process followed by an overview of reactor conditions which affect the performance of nitrogen removal. Furthermore, process conditions were examined to find out the optimal parameters for specific application. Findings of this literature review would help researchers to understand the process performance and the interactions between process parameters and reactor configuration within the systems. 


\section{Nitrogen Removal Process}

\subsection{Nitrification-denitrification over nitrate}

Biological nitrification-denitrification over nitrate occurs in two separate processes which were proceeded by two different group of bacteria. During nitrification, ammonium is oxidized to nitrate where initially ammonium oxidizing bacteria (AOB) oxidize ammonium to nitrite $\left(\mathrm{NO}_{2}{ }^{-}\right)$(Path-1 in Fig. 1 and Eq. 1 in Table 1) and then nitrite oxidizing bacteria (NOB) oxidize nitrite to nitrate $\left(\mathrm{NO}_{3}{ }^{-}\right)$(Path-2 in Fig. 1 and Eq. 2 in Table 1). During denitrification, nitrate is transformed to nitrite and finally into nitrogen gas (Paths-3 \& 4 in Fig. 1 and Eqs. 3 \& 4 in Table 1). In heterotrophic denitrification, reduction process happens in four steps, nitrogen gas $\left(\mathrm{N}_{2}\right)$ produces from nitrate $\left(\mathrm{NO}_{3}{ }^{-}\right)$ over nitrite $\left(\mathrm{NO}_{2}{ }^{-}\right)$, nitric oxide $(\mathrm{NO})$ and nitrous oxide $\left(\mathrm{N}_{2} \mathrm{O}\right)$ where different enzymes catalyze each step [8]. If one or more individual reduction steps slow down for any reason, intermediate products accumulation occur in the system which ultimately contribute to reduce nitrogen removal [9].

Considering relatively easy operation and moderate cost, biological nitrificationdenitrification over nitrate was widely used as an efficient process [10]. Detailed advantages and disadvantages of this system were described in Table 2. Generally, this process was used for the treatment of wastewater containing low nitrogen concentration ( $<100 \mathrm{mg} \mathrm{N} / \mathrm{L}$ ) and was more favorable for ammonium nitrogen removal process compare to chemical precipitation or air stripping [11].

Table 1. Reactions of nitrogen removal pathways.

\begin{tabular}{|c|c|}
\hline \multirow{2}{*}{\multicolumn{2}{|c|}{$\begin{array}{l}\text { 1. Nitrification-denitrification over nitrate } \\
\text { Nitrification: }\end{array}$}} \\
\hline & \\
\hline $\mathrm{NH}_{4}^{+}+1.5 \mathrm{O}_{2}=\mathrm{NO}_{2}^{-}+2 \mathrm{H}^{+}+2 \mathrm{H}_{2} \mathrm{O}$ & $\ldots(1)$ \\
\hline $\mathrm{NO}_{2}^{-}+0.5 \mathrm{O}_{2}=\mathrm{NO}_{3}^{-}$ & $\ldots(2)$ \\
\hline Denitrification: & \\
\hline $2 \mathrm{NO}_{3}^{-}+10 \mathrm{H}^{+}+10 \mathrm{e}^{-}=\mathrm{N}_{2}+2 \mathrm{OH}^{-}+4 \mathrm{H}_{2} \mathrm{O}$ & $\ldots(3)$ \\
\hline $2 \mathrm{NO}_{2}^{-}+6 \mathrm{H}^{+}+6 \mathrm{e}^{-}=\mathrm{N}_{2}+2 \mathrm{OH}^{-}+2 \mathrm{H}_{2} \mathrm{O}$ & $\ldots(4)$ \\
\hline 2. Nitrification-denitrification over nitrite & \\
\hline Nitrification: & \\
\hline $\mathrm{NH}_{4}^{+}+1.5 \mathrm{O}_{2}=\mathrm{NO}_{2}^{-}+2 \mathrm{H}^{+}+2 \mathrm{H}_{2} \mathrm{O}$ & $\ldots(1)$ \\
\hline Denitrification: & \\
\hline $\mathrm{NO}_{2}^{-}+0.5 \mathrm{C}+\mathrm{H}^{+} \rightarrow \mathrm{N}_{2}+\mathrm{CO}_{2}+\mathrm{H}_{2} \mathrm{O}$ & $\ldots(5)$ \\
\hline $\begin{array}{l}\text { 3. Anaerobic ammonium oxidation (Anammox) } \\
\mathrm{NH}_{4}^{+}+1.32 \mathrm{NO}_{2}^{-}+0.13 \mathrm{H}^{+} \rightarrow 1.02 \mathrm{~N}_{2}+0.26 \mathrm{NO}_{3}^{-}+2.03 \mathrm{H}_{2} \mathrm{O}\end{array}$ & $\ldots(6)$ \\
\hline 4. Partial nitrification combined with Anammox & \\
\hline $2 \mathrm{NO}_{3}^{-}+12 \mathrm{H}^{+}+10 \mathrm{e}^{-}=\mathrm{N}_{2}+6 \mathrm{H}_{2} \mathrm{O}$ & $\ldots(7)$ \\
\hline $\begin{array}{l}\mathrm{NH}_{4}^{+}+1.32 \mathrm{NO}_{2}^{-}+0.066 \mathrm{HCO}_{3}^{-}+0.13 \mathrm{H}^{+}=0.066 \mathrm{CH}_{2} \mathrm{O}_{0.5} \mathrm{~N}_{0.15}+1.02 \mathrm{~N}_{2}+0.26 \mathrm{NO}_{3}^{-}+ \\
2.03 \mathrm{H}_{2} \mathrm{O}\end{array}$ & $\ldots(8)$ \\
\hline $\mathrm{NH}_{4}^{+}+0.85 \mathrm{O}_{2}=0.44 \mathrm{~N}_{2}+0.11 \mathrm{NO}_{3}^{-}+1.43 \mathrm{H}_{2} \mathrm{O}+0.14 \mathrm{H}^{+}$ & $\ldots(9)$ \\
\hline 5. Simultaneous nitrification and denitrification (SND) & \\
\hline Nitrification: & \\
\hline $\mathrm{NH}_{4}+1.5 \mathrm{O}_{2}+2 \mathrm{HCO}_{3}^{-} \rightarrow \mathrm{NO}_{2}^{-}+3 \mathrm{H}_{2} \mathrm{O}+2 \mathrm{CO}_{2}$ & $\ldots(10)$ \\
\hline Denitrification: & (11) \\
\hline
\end{tabular}




\subsection{Nitrification-denitrification over nitrite}

Under controlled aeration, ammonium is oxidized to nitrite only (Path-1 in Fig. 1 and Eq. 1 in Table 1) but not nitrate that reduced $25 \%$ aeration cost. The denitrification of nitrite to nitrogen gas is produced in the presence of external carbon source (Path-4 in Fig. 1 and Eq. 5 in Table 1). In equations, $\mathrm{C}$ denotes the carbon source; carbon dioxide $\left(\mathrm{CO}_{2}\right)$ for autotrophic denitrification and organic carbon for heterotrophic denitrification. nitrification-denitrification over nitrite needed less external carbon source, save $40 \%$ cost, as well as emitted less carbon dioxide $\left(\mathrm{CO}_{2}\right)$ and produced less sludge compare to conventional nitrification-denitrification over nitrate (Table 2).

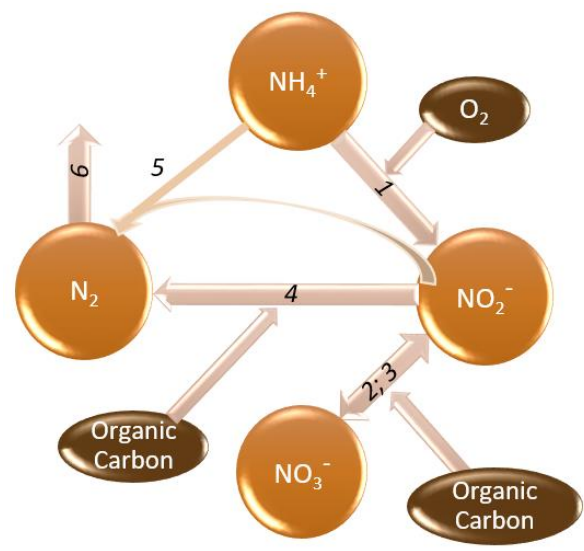

Fig. 1. Microbial pathways in nitrogen transformation.

\subsection{Anaerobic ammonium oxidation (anammox)}

Ammonium oxidation not only proceed under aerobic conditions but also under anaerobic conditions [1]. Anammox was more efficient biological alternative to conventional nitrogen removal. Under anaerobic conditions, ammonium was oxidized to nitrogen gas using nitrite as the electron acceptor (Path-5 in Fig. 1 and Eq. 6 in Table 1) and carbon dioxide as a carbon source. However, existence of organic source had a negative effect on the anammox process $[12,13]$. If certain amount of organic carbon exists, the growth rate of denitrifiers was higher than anammox and as a consequence anammox bacteria compete out by denitrifiers [14]. As the process was anoxic that eventually decreased aeration cost. Furthermore, anammox bacteria consumed $\mathrm{CO}_{2}$ as a carbon source and hence organic compounds addition was not required.

There was low operating cost for anammox process; $100 \%$ less organic carbon consumption and $50 \%$ less oxygen consumption compare to traditional nitrificationdenitrification [15] (Table 2). The growth rate of anammox is relatively slowly and it took long start-up time for sufficient biomass for operation [16]. The process produced various intermediate products such as hydrazine, hydroxylamine, $\mathrm{NO}_{\mathrm{x}}$ etc. [17]. The electron acceptor nitrite was reduced to hydroxylamine which further reacts with ammonium to 
produce nitrogen gas. Transient hydrazine accumulated as an intermediate product by excess hydroxylamine and ammonium [18]. Free hydrazine in microbial nitrogen metabolism was rare, but normally hydrazine was oxidized to nitrogen gas where electrons were generated for initial reduction of nitrite to hydroxylamine [19].

Anaerobic ammonium oxidizing bacteria (AnAOB) are the autotrophic bacteria. Recently five genera of AnAOB were reported; such as Candidatus Brocadia, Candidatus Kuenenia, Candidatus Scalindua, Candidatus Anammoxoglobus and Candidatus Jettenia, but the most common AnAOB were Brocadia Anammoxidans and Kuenenia Stuttgartiensis $[14,20]$. Both bacteria shown high anammox activity in a wide range of $\mathrm{pH}$ 6.4 - 8.3, temperature $20-43{ }^{\circ} \mathrm{C}$ [21] and tolerate high $\mathrm{O}_{2}$ concentrations (up to $13 \mu \mathrm{mol} / \mathrm{L}$ ) [22]. They can work on low $\mathrm{C} / \mathrm{N}$ ratios (above 1). Anammox bacteria were no longer able to compete with heterotrophic denitrifying bacteria. High COD adversely affect the anammox activities. Above $300 \mathrm{mg} C O D / \mathrm{L}$ with fat milk feed inactivated the anammox communities [12]. $50 \mathrm{mM}$ acetate concentration inhibits $70 \%$ of anammox activities [23]. Therefore, COD level was necessary to control for smooth anammox operation.

Table 2. Comparison among nitrogen removal processes.

\begin{tabular}{|c|c|c|}
\hline Process & Advantages & Limitations \\
\hline $\begin{array}{l}\text { N/D over } \\
\text { nitrate }\end{array}$ & $\begin{array}{l}\text { - Easy operation } \\
\text { - Moderate cost } \\
\text { - } 96 \% \text { Ammonia removal }\end{array}$ & $\begin{array}{l}\text { - Low COD/N ratio } \\
\text { preferable } \\
\text { - High external carbon } \\
\text { source and oxygen } \\
\text { required } \\
\text { - Applicable for low } \\
\text { nitrogen containing } \\
\text { wastewater }\end{array}$ \\
\hline $\begin{array}{l}\text { N/D over } \\
\text { nitrite }\end{array}$ & $\begin{array}{l}\text { - Reduction of } 25 \% \text { aeration cost } \\
\text { - } 40 \% \text { less external carbon source } \\
\text { - Less } \mathrm{CO}_{2} \text { and sludge production }\end{array}$ & $\begin{array}{l}\text { - Require external organic } \\
\text { carbon source and oxygen }\end{array}$ \\
\hline Anammox & $\begin{array}{l}\text { - } 100 \% \text { less organic carbon consumption } \\
\text { - } 50 \% \text { less oxygen consumption } \\
\text { - Less aeration cost }\end{array}$ & $\begin{array}{l}\text { - Existence of organic matter } \\
\text { has detrimental effect } \\
\text { - Slow growth rate of } \\
\text { anammox organism }\end{array}$ \\
\hline CANON & $\begin{array}{l}\text { - Upto } 62.5 \% \text { less oxygen consumption } \\
\text { - Non-requirement of organic carbon } \\
\text { - Low process cost } \\
\text { - Single stage reactor is possible to use } \\
\text { - Effective in both low and high COD/N ratio } \\
\text { - Adverse temperature and toxic shock can be mitigated }\end{array}$ & $\begin{array}{l}\text { - Sensitive operational } \\
\text { characteristics }\end{array}$ \\
\hline SND & $\begin{array}{l}\text { - Low operating time } \\
\text { - Operation in a single reactor with identical } \\
\text { operating condition } \\
\text { - } 95 \% \text { total nitrogen removal } \\
\text { - Reduction of } 40 \% \text { energy consumption } \\
\text { - } 300 \% \text { less biomass production } \\
\text { - Faster consumption of Ammonia, Nitrite and Nitrate }\end{array}$ & $\begin{array}{l}\text { - Require external carbon } \\
\text { source } \\
\text { - Need to optimum and } \\
\text { proper control DO } \\
\text { operation }\end{array}$ \\
\hline
\end{tabular}




\subsection{Partial nitrification combined with anammox}

Combining anammox reaction with partial nitrification in one reactor, entitled CANON (completely autotrophic nitrogen removal over nitrite) was one of promising alternative for removal of ammonium-nitrogen. It proceeded through partial nitrification to convert ammonium to nitrite and subsequent anammox process for complete removal. In this process nitrifiers oxidize half of ammonium to nitrite under controlled oxygen condition which consequently passed through anoxic conditions for anammox reaction (Path-1 in Fig. 1 and Eq. 8 in Table 1). The produced nitrite was utilized with the remaining ammonium by anammox bacteria and converted into nitrogen gas (Path-5 in Fig. 1 and Eq. 1 in Table 1). It was found that a CANON system, Nitrosomonas acted as AOB and Planctomycete as anammox and performed two sequential reactions simultaneously under oxygen limited condition [24]. CANON process takes place in a single reactor in which $\mathrm{AOB}$ and anammox coexist in a biofilm or form compact granules. Batch experiments and microbial analysis showed that nitrite was at the outer biofilm layer; controlled by the diffusion of oxygen. The remaining ammonium and nitrite diffused into the deeper part of the biofilm where anoxic conditions were maintained and nitrite acts as an electron acceptor which reacts with the remaining ammonium to form nitrogen gas. For the efficient process, a balanced relationship between AOB and anammox was needed [25].

CANON process has a number of advantages that described in Table 2. It required 50 $62.5 \%$ less oxygen and no organic carbon, leads low process cost [26]. The success of CANON process depends on the continuous suppression of nitrite oxidizers and efficiently control the nitrite to ammonium ratio (optimum stoichiometric ratio is 1.32). However increase of either ammonium or nitrite reduced the performance of anammox activities [23]. CANON process has quite sensitive operational characteristics for dissolved oxygen, nitrogen-surface load, biofilm thickness and temperature [27]. Oxygenmass transfer efficiency from gas to liquid phase and effective biomass retention were two key rate limiting factors for CANON process [28]. Moreover, growth rate of autotrophic AOB was lower than that of heterotrophic bacteria, with which they had to compete for oxygen. Without long retention times, suspended nitrifiers would be easily washed out. Biomass concentration was increased by recirculation of sludge, but limited by the efficiency of sedimentation. In addition, ammonia oxidation rate was strongly influenced by nature of nitrifying cultures and environmental factors including substrate concentration, dissolved oxygen, temperature and $\mathrm{pH}$. To scale up the CANON system from laboratory to industrial application was the most challenge [29]. Immobilization was an efficient method to reduce wash out of nitrifiers and make a concentrated culture. Ultimately, it reduced the space volume but provided some protection from adverse temperatures and toxic shocks which help to run the operation for a long period [30].

\subsection{Simultaneous nitrification and denitrification (SND)}

SND was the combination of two individual process, nitrification and denitrification. It started with partial nitrification of $\mathrm{NH}_{4}{ }^{+}$to nitrite (Path-1 in Fig. 1 and Eq. 10 in Table 1), 
subsequently nitrite to $\mathrm{N}_{2}$ gas through denitrification (Path-4 in Fig. 1 and Eq. 11 in Table 1). The process contained two steps lower compare to conventional nitrificationdenitrification and hence took low operating time. The process occurred in a single reactor under identical operating condition that reduced reactor volume as well as energy cost for recirculation. Various SND reactor configurations, such as, (i) flexible biofilm reactor having adjustable aerobic and anoxic zones with liquid circulation depending on aeration flow rate [31], (ii) biofilm airlift suspension reactor with biodegradable carrier material [32], and (iii) a bench-scale continuous flow system which can simultaneously remove nitrogen and carbon [33] were widely used. The nitrogen removal pathway via nitrite gave advantages by reduction of COD demand for denitrification, high rate of denitrification, low biomass yield and no nitrite toxicity [34]. SND was effective at neutral $\mathrm{pH}$ and no $\mathrm{pH}$ change during the process, saved the cost for $\mathrm{pH}$ control [35].

Co-immobilize nitrifiers and denitrifiers in a packed gel envelopes was capable to use as SND [36]. Immobilized Nitrosomonas Europaea oxidize ammonia to nitrite on the outer surface of the plate which was in aerobic contact. Immobilized Paracoccus Denitrificans reduced nitrite to nitrogen gas on the inside of the plate that was in anaerobic with organic carbon. This system did not require an additional aerobic step because the organic carbon was not supplied to the wastewater directly but to the internal space of the gel plates. Utilization efficiency of organic carbon increased denitrification and decreased the quantity of surplus sludge. In another attempt, a bioreactor system with 30 packed gel envelopes was installed to treat ammonia-contained desulfurized wastewater to remove ammonia in a single step. In a continuous operation, the process removed $95 \%$ total nitrogen with outlet concentration $9 \mathrm{mg} / \mathrm{L}$. Since the bioreactor system could use the organic carbon effectively, it was not necessary to use additional aerobic tank to remove organic carbon and settling tank for surplus sludge [37].

Oxygen diffusion was a control handle to create anoxic zone in a flocks for heterotrophic denitrification, SND occurs in oxidation ditch [38] and sequencing batch reactor (SBR) [39]. Carbon supply, oxygen concentration and flock size combined responsible for the process efficiency. Adding readily biodegradable COD increased the activity and DO decreased the activity that ultimately produces a larger flock [40]. Dissolved oxygen concentration gradient within the granule, formation of aerobic and anoxic condition was dependent on size and structure of flocks. Oxygen diffusion coefficients were dependent on the structure of the outer layers of flocks that determined the efficient partial nitrification in low-oxygen concentration with autotrophic microorganisms [41].

SND process was more economical to any of the process due to faster consumption of ammonia, nitrite and nitrate [31]. Efficient handling reduced near about $40 \%$ energy consumption with increasing $63 \%$ in denitrification. If no nitrite inhibition was produced $300 \%$ less biomass and $75 \%$ oxygen consumption was solely needed only for nitritation than to complete oxidation to nitrate [42] (Table 2). 


\section{Effect of Operating Parameters}

Various process parameters such as oxygen concentration, external carbon source, temperature, $\mathrm{pH}$ etc. had a significant effect on biological nitrogen removal activity.

\subsection{Dissolved oxygen concentration}

Dissolved oxygen concentration was crucial for both ammonium and nitrite oxidation. Lower than $2 \mathrm{mg} \mathrm{O}_{2} / \mathrm{L}$ showed limiting effect on nitrification [43]. Due to higher oxygen affinity, ammonium oxidizers were more vigorous at low oxygen concentration then nitrite oxidizers. Whereas, oxygen deficiency influences the performance of nitrite oxidizers more significantly than the ammonium oxidizers [44]. Half saturation constant for ammonium oxidizers was $0.16 \mathrm{mg} \mathrm{O}_{2} / \mathrm{L}$ and for nitrite oxidizers was $0.54 \mathrm{mg} \mathrm{O} / \mathrm{L}$ [45]. However, in an activated sludge process, oxygen half saturation constants was found $0.25-0.5 \mathrm{mg} \mathrm{O}_{2} / \mathrm{L}$ for ammonium oxidizers and for nitrite oxidizers it was $0.34-2.5 \mathrm{mg}$ $\mathrm{O}_{2} / \mathrm{L}$ [46]. This variability was due to the variation of oxygen concentration inside the sludge matrix and in the bulk liquid. Half saturation constant depends on a number of parameters such as biomass density, size of sludge matrix, mixing intensity and rate of diffusion of oxygen into the sludge matrix etc. [47].

The success of nitrification-denitrification over nitrite was dependent on controlling dissolved oxygen. High oxygen was favorable for nitrite oxidizers, resulting in nitrate formation. In oxygen limiting conditions nitrite oxidizers were outcompeted and nitrite accumulates. Nitrogen removal over nitrite could be established by turning off aeration at the point where ammonium oxidation has completed. By frequently changing between aerobic and anoxic in an activated sludge system, nitrate formation was effectively reduced [48].

Anammox process was strictly anaerobic process which was inhibited by oxygen concentration. The anammox metabolism was reversible at low oxygen concentration $(0.25-2 \%$ air saturation), but irreversible at high concentration (18\% air saturation or, more) [41]. In partial nitritation-anammox process, oxygen was needed for converting half of ammonium to nitrite but conversion to nitrogen gas from unconverted ammonium and nitrite through anammox process was completely anaerobic. Nitrate formation predominated at high oxygen concentration but not at low oxygen concentration. A decrease in oxygen concentration or an increase in flock, washed out NOB and activity of minor NOB fraction in biofilm was suppressed [49].

\subsection{Temperature}

Temperature affects nitrification process directly as well as indirectly. A higher temperature increased microbial growth according to the Arrhenius law, which was valid up to a certain critical temperature, above which biological activity started to decrease. Optimum temperature range was 35 to $45{ }^{\circ} \mathrm{C}$ for ammonium oxidizers and $38{ }^{\circ} \mathrm{C}$ for nitrite oxidizers [50]. High temperature of $28-38{ }^{\circ} \mathrm{C}$ was favorable for nitrogen removal 
via nitrite due to the fact that the specific growth rate of AOB was higher than NOB [51]. Nitritation can be maintained at room or low temperature and nitratation start-up can be promoted and accelerated at high temperature [52]. In temperature $10-20{ }^{\circ} \mathrm{C}$ resulted a very low nitrite accumulation due to high specific growth rate of NOB than AOB [53]. Therefore, relatively low wastewater temperature specially winter season in Bangladesh was the major obstacle behind the full-scale application of nitrogen removal via nitrite. Nitritation could be achieved at a temperature of $19 \pm 1{ }^{\circ} \mathrm{C}$ by controlling dissolved oxygen (DO) concentration and $\mathrm{pH}$. AOB dominance can be enhanced through low DO concentration ( $<1.0 \mathrm{mg} / \mathrm{L})$ and short-cycle aeration time [54].

Rotating biological contactor (RBC) with anammox process could be operated at temperature around $20{ }^{\circ} \mathrm{C}$ [55]. Moreover, anammox activity was found between -2 and $30{ }^{\circ} \mathrm{C}$ with sediments of east and west coasts of Greenland where optimum temperature was $12{ }^{\circ} \mathrm{C}$ [56]. These results indicated that anammox process application should not be restricted to effluents with temperature around $30{ }^{\circ} \mathrm{C}$. Moderate to low temperature reduced the stability of anammox and maximum activity was at $35-40{ }^{\circ} \mathrm{C}$ [57]. The system operated successfully at $18{ }^{\circ} \mathrm{C}$ but temperature decreased to $15{ }^{\circ} \mathrm{C}$ shown nitrite accumulation. In contrary, denitrification rate showed weak dependence on temperature, maximum denitrification rate remained constant at $3{ }^{\circ} \mathrm{C}$ during 8-day period [58].

\section{3. $p H$}

The optimum $\mathrm{pH}$ for both ammonium oxidizers and nitrite oxidizers lies between 7 and 8 [59]. The ammonium oxidizers preferred alkaline environment as they used ammonia $\left(\mathrm{NH}_{3}\right)$ as substrate and maintained inorganic carbon $\left(\mathrm{HCO}_{3}{ }^{-}\right)$for metabolism of nitrifying bacteria. Growth rate of nitrite oxidizers decreases by the factor 8 for changing $\mathrm{pH}$ from 8 to 7, whereas change of growth rate of ammonium oxidizer was negligible [60].

Strongly acidic environment $(\mathrm{pH}<5)$ inhibit denitrification chain with formation of nitrite or $\mathrm{N}_{2} \mathrm{O}$ [61]. Heterotrophic denitrification itself increased the $\mathrm{pH}$ as it releases hydroxyl ions and raises alkalinity. Every $\mathrm{mg}$ of $\mathrm{NO}_{3}-\mathrm{N}$ reduced to $\mathrm{N}_{2}$ which increases the alkalinity of $3.57 \mathrm{mg} \mathrm{CaCO}$ following the stoichiometry of reaction-7 (Table 1). Optimum $\mathrm{pH}$ for growth of denitrifying organism Thiobacillus denitrificans was between 6.8 and 8.2. The maximum efficiency was at $\mathrm{pH} 8.4$ and decreased to zero at 5.5 [62]. However, Lee and Rittmann [63] found decreasing of nitrate removal rate as well as increasing of nitrite accumulation with increasing $\mathrm{pH}$ above 8.6.

Anammox bacteria can grow in $\mathrm{pH}$ range of 6.7 to 8.3 , but optimum $\mathrm{pH}$ was 8.0 [14]. $\mathrm{pH}$ influences the concentration of free ammonia $\left(\mathrm{NH}_{3}\right)$ and free nitrous acid $\left(\mathrm{HNO}_{2}\right)$ that were function of ammonium and nitrite respectively and inhibit nitrification [64]. Nitrite played crucial role in nitrogen removal; limitation for NOB at low concentration. High nitrite concentration (>100 mg N/L) inhibited anammox activities [14] and microbial activities are completely lost at or above $185 \mathrm{mg} \mathrm{N} / \mathrm{L}$ [21]. The amount of nitrite $\left(\mathrm{NO}_{2}{ }^{-}\right)$ accumulation was increased with increasing $\mathrm{pH}$. 


\subsection{Effect of free ammonia $(F A)$ concentration}

Free ammonia and free nitrite, concentrations need to keep below $2 \mathrm{mg} \mathrm{N} / \mathrm{L}$ and $35 \mathrm{mg}$ $\mathrm{N} / \mathrm{L}$ respectively for continuous growth of anammox bacteria [65]. Ammonium and nitrite oxidation were inhibited by free ammonia; Nitrobacter inhibited nitrite oxidation at 0.1 $1.0 \mathrm{mg}$ FA/L, while Nitrosomonas inhibited ammonium oxidation at $10-150 \mathrm{mg} \mathrm{FA} / \mathrm{L}$. There were also selective inhibition of nitrite oxidation at FA concentration $1.0-10 \mathrm{mg} / \mathrm{L}$ $[64,66]$. Nitrite accumulation was resulted from higher activities of AOB than NOB that was undesirable. In general, NOB was more sensitive to free ammonia and nitrous acid inhibited ammonium oxidation. At high $\mathrm{pH}(>8)$, free ammonia becomes the main inhibitor for the nitrification process and at low $\mathrm{pH}(<7.5)$ nitrous acid becomes the main inhibitor.

\subsection{Effect of nitrate concentration}

Excess nitrate concentration affects denitrification process by inhibiting formation of $\mathrm{N}_{2}$ gas and the process was terminated with $\mathrm{N}_{2} \mathrm{O}$ formation [67]. Organism presented in denitrification, broadly divided into two categories which were nitrate tolerant and nitrate intolerant. Nitrate tolerant bacteria include nitrate respirators (capable of reducing nitrate to nitrite) and true denitrifiers (capable of reducing nitrate to nitrogen). The growth rate of nitrate tolerant and nitrate intolerant bacteria varies depending upon nitrate concentrations. At high nitrate concentration, the population of nitrate tolerant bacteria multiplies faster than that of nitrate intolerant bacteria. Thus, acclimatization was important to obtain desired population balance by subjecting them at controlled nitrate concentration.

\subsection{Effect of culture medium}

Suitable medium selection was one of the most important parameters needed to be considered in bacterial ecology. Various culture mediums had been developed for studying biological nitrogen removal. The culture medium consisted of various stimulating and inhibiting factors. Nitrifiers needed $1 \mathrm{mg} / \mathrm{L}$ calcium for optimum growth of Nitrosomonas where phosphate and magnesium were essential for Nitrosomonas and Nitrobacter [68]. Iron dose stimulated nitrification in pure cultures; minimum dose was $0.1 \mathrm{mg} / \mathrm{L}$ for Nitrosomonas, $0.3 \mathrm{mg} / \mathrm{L}$ for Nitrobacter; optimum dose was about $6 \mathrm{mg} / \mathrm{L}$ for both species which tolerate up to $12 \mathrm{mg} / \mathrm{L}$. Copper was essential for nitrifiers but not zinc, manganese, sodium butyrate and asparagin due to toxicity even in small doses [68].

Small dose of glucose, peptone, asparagine, sodium butyrate and large dose of urine and sodium acetate stop nitrification [69]. Peptone was very poisonous to nitrifiers but peptone with free amino-acids was most toxic. Sodium acetate improved the growth of Nitrosomonas and Nitrobacter, even though sodium acetate did not use as carbon source. In mixed cultures, yeast extract, thiamin and urine had no stimulating effect on nitrification at low concentration; but stopped nitrification at high concentration [68]. 
$\mathrm{NaHCO}_{3}, \mathrm{Na}_{2} \mathrm{HPO}_{4}, \mathrm{KH}_{2} \mathrm{PO}_{4}, \mathrm{MgSO}_{4}, \mathrm{CaCl}_{2}, \mathrm{FeCl}_{3}$, agar could be used as growth medium for nitrifying bacteria [70]. Removal rate of ammonia remains almost the same while dropping ammonia from $0.212 \mathrm{~g} / \mathrm{L}$ to zero at $30 \mathrm{~h}$ [70]. Mixture of organic and inorganic carbon source enhanced cell growth and ammonium nitrogen removal rate. High Fe concentration enhanced anammox reaction; higher than $120 \mathrm{mg} \mathrm{Fe} / \mathrm{L}$ reduced anammox reaction time from 5 to $2 \mathrm{~h}[71]$.

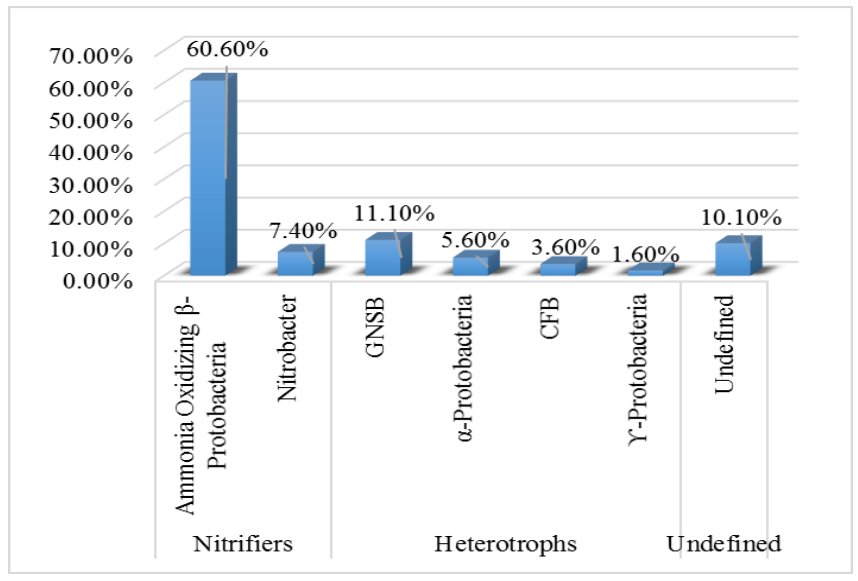

Fig. 2. Biomass distribution profile in nitrifying granule (Source [73]).

\section{Influence of COD/N Ratio on Biological Nitrogen Removal}

In biological nitrogen removal process, autotrophic and heterotrophic bacteria coexist. In conventional nitrogen removal through nitrification-denitrification over nitrate, nitrification was an autotrophic but denitrification was a heterotrophic process where external organic carbon was needed. In case of complete autotrophic nitrogen removal through partial nitritation-anammox, no organic carbon source was required. Even if influent did not contain organic carbon, heterotrophic growth occurred on organic material generated from biomass decay or excretion of living cells [54,72].

In autotrophic biofilm process, ammonium oxidize to nitrite without external carbon source where heterotrophic growth occurs based on decay of nitrifying bacteria; the resulting biomass distribution profile, which revealed $22 \%$ heterotrophs and $68 \%$ nitrifying bacteria (AOB and NOB) in nitrifying granule as shown in Fig. 2 [73].

Heterotrophic bacteria in the treatment system consumed COD as well as generated COD by decay. Simultaneous effect of influent COD and sludge retention time (SRT) on the heterotrophic biomass fraction in nitrifying sequencing batch reactor (SBR) was shown in Fig. 3, where influent COD yields about $40 \%$ of the total heterotrophic biomass and remaining $60 \%$ results from decay. Heterotrophic biomass increased by $11 \%$ with increasing SRT from 30 to 100 days due to decay product with SRT [74]. 


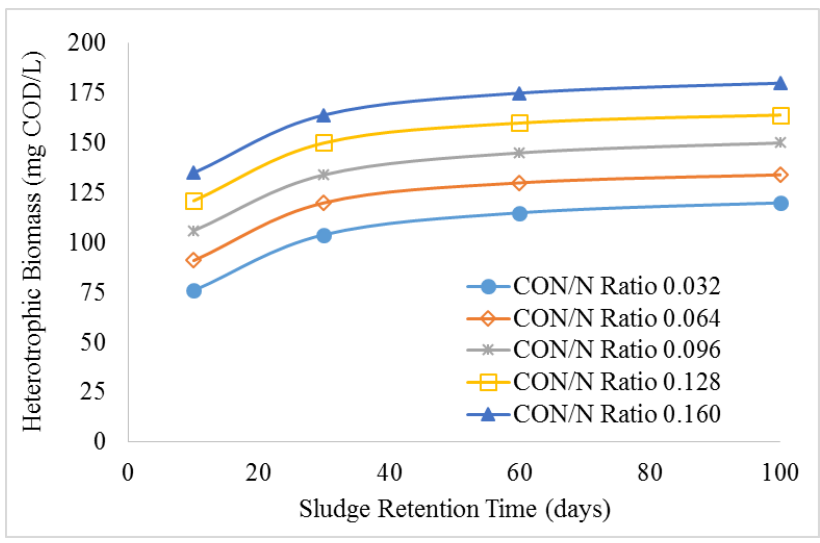

Fig. 3. Effect of influent $\mathrm{COD} / \mathrm{N}$ ratio on heterotrophic biomass concentration vs SRT in nitrification-denitrification via nitrate [74].

\subsection{Nitrification-denitrification over nitrate}

Influent $\mathrm{COD} / \mathrm{N}$ ratio affects both nitrifying and denitrifying population in biological nitrogen removal. The performance of both AOB and NOB significantly increased with decreasing influent $\mathrm{COD} / \mathrm{N}$ ratio in granular sludge reactor. Low $\mathrm{COD} / \mathrm{N}$ ratio gave advantages to nitrifying bacteria for high oxygen utilization rate compare to heterotrophic oxygen utilization rate; low $\mathrm{COD} / \mathrm{N}$ ratio was favorable for nitrification [75]. At high organic carbon, heterotrophic bacteria grew excessively and compete with AOB for oxygen which reduced the nitrification process. High organic concentration stimulated biofilm growth as well as increased the diffusion resistance of ammonium into the biofilm which ultimately reduces the nitrification.

Nitrification rate exponentially decreased with changing COD/N ratio from 0.71 to 3.4 and relationship was expressed as Eq. 12 [76].

$$
r_{\text {nitrification }}=0.0323+0.334 \mathrm{e}^{(-1.660(\mathrm{COD} / \mathrm{N}))} \text {. }
$$

Influent $\mathrm{COD} / \mathrm{N}$ ratio was not only affect the nitrification rate but also nitrification capacity. The nitrifying biomass fraction in a biofilm increased with decreasing COD/N ratio [77]. Autotrophic biomass fraction was increased by 1.5 to $2 \%$ with decreasing COD/N ratio from 3.4 to 2.6 [78]. The relationship was also described by Eq. 13 [76].

$$
\text { Nitrifiers' fraction }=0.0265+0.508 \mathrm{e}^{(-2.39(\mathrm{BOD} 5 / \mathrm{TKN}))}+0.21 \mathrm{e}^{(-0.43(\mathrm{BOD} 5 / \mathrm{TKN}))} \ldots \ldots
$$

According to Eq. 13, nitrifying biomass was decreased with increasing $\mathrm{BOD}_{5} / \mathrm{TKN}$ ratio. Moreover, nitrification rate remained constant ( $0.032 \mathrm{~g} \mathrm{~N} / \mathrm{g}$ VSS/day) at COD/N higher than 4 and at least 7.1 was required for complete denitrification [76].

The nitrification and denitrification efficiency was decreased with increasing influent ammonium loading from 2.0 to $11.5 \mathrm{~g} \mathrm{~N} / \mathrm{m}^{2} / \mathrm{d}$ in a biofilm reactor which was resulted for a limited surface area of biofilm that caused insufficient nitrification. But nitrification and denitrification rates increase to peak value and then decrease at the highest ammonium 
loading. At highest ammonium loading, some part of it transformed into free ammonia, which was toxic to most microorganisms and decreased nitrification and denitrification rates. Overall nitrification efficiency was decreased with COD concentration while denitrification efficiency was increased [79]. A higher influent COD/N ratio led to higher residual COD resulted complete denitrification, while a lower influent $\mathrm{COD} / \mathrm{N}$ ratio caused incomplete denitrification [80].

Membrane aerated biofilm reactor (MABR) was advanced technology for simultaneous removal of organic compounds and nitrogen from wastewater [72, 81]. In MABR, COD and nitrogen removal depended on oxygen concentration in the gas stream and influent $\mathrm{COD} / \mathrm{N}$ ratio. In MABR, $96 \%$ ammonium removal was achieved for $\mathrm{COD} / \mathrm{N}$ ratio 3 but effluent nitrate $\left(\mathrm{NO}_{3}{ }^{-}\right)$was sharply decreased with increasing COD/N ratio up to 5. Effluent ammonium concentration was also increased with increasing $\mathrm{COD} / \mathrm{N}$ ratio to $6[82]$.

\subsection{Anammox process}

Presence of organic matter had a negative effect on anammox process [12,13]. Anammox process did not require organic carbon. If certain amount of organic carbon was present, the growth rate of denitrifiers becomes higher than anammox bacteria where anammox bacteria could not compete with denitrifiers [14]. Lowering the influent COD/N ratio, which control denitrifiers, higher nitrogen removal occur through anammox process.

A hybrid anaerobic-aerobic baffled reactor (HAOBR) was applied with an average $\mathrm{COD} / \mathrm{TN}$ ratio as low as 0.98 and removal $\mathrm{COD}, \mathrm{NH}_{4}{ }^{+}-\mathrm{N}$ and total nitrogen $87.0 \%, 100$ $\%$ and $91.3 \%$, respectively. Anammox and heterotrophic denitrification were the dominant approach to removal of total nitrogen [83]. It indicated that simultaneous anammox and denitrification process could proceed [84].

\subsection{Partial nitritation-anammox}

Considering heterotrophic growth on decay biomass only, nitrogen removal efficiency decreased for counter diffusion biofilm but no significant difference for co-diffusion. In counter diffusion, anammox denitrification dominates at COD/ $\mathrm{N}$ ratio of 0 but for $\mathrm{COD} / \mathrm{N}$ ratio equal or higher than 2, there was no autotrophic denitrification [72]. Under increasing COD load anammox bacteria were outcompeted by denitrifying heterotrophic bacteria and nitrogen removal was occurred due to heterotrophic denitrification. In codiffusion system, anammox fraction was almost constant but heterotrophic bacteria slightly increased and ammonium oxidizing bacteria was decreased with COD/ $\mathrm{N}$ ratio.

\section{Conclusion}

Partial nitrification combined with anaerobic ammonium oxidation was the most prospective nitrogen removal technique for wastewater treatment compare to other nitrogen removal techniques (conventional nitrification-denitrification over nitrate or 
nitrite, anammox, SND etc.) due to the less oxygen consumption (62.5\% less), less sludge production, non-requirement of carbon source, single reactor used and energy efficiency. In this process nitrite to ammonium ratio should be 1.32 . However, increase of either ammonium or nitrite reduced the performance of anammox activities.

SND process was more economical to any of the process due to faster consumption of ammonia, nitrite and nitrate. Co-immobilize nitrifiers and denitrifiers in a packed gel envelope may one of alternatives for efficient application of SND.

The effectiveness of nitrogen removal process depends on the influent characteristics (COD/N ratio) and operating parameters (oxygen concentration, temperature, $\mathrm{pH}$, organic carbon concentration, culture medium etc.). Oxygen concentration limits the ammonium oxidation to nitrite formation $\left(0.16-0.5 \mathrm{mg} \mathrm{O}_{2} / \mathrm{L}\right)$ in lieu of forming nitrate $(0.34-2.5$ $\mathrm{mg} \mathrm{O}_{2} / \mathrm{L}$ ) that means oxygen concentration determines the nitrogen removal pathways; nitrification-denitrification over nitrite or nitrate. According to Arrhenius law, microbial growth rate increases with increasing temperature, which was valid up to certain critical temperature. The temperature $28-38{ }^{\circ} \mathrm{C}$ was found optimum for nitrogen removal from wastewater. Most of the research revealed that optimum $\mathrm{pH}$ for nitrogen removal processes lies in the range 7 to 8 but nitrification and denitrification process was inhibited above $\mathrm{pH} 8$ and below 5 respectively. Free ammonia (FA) concentration prescribed the inhibition of nitrite oxidation $(0.1-1 \mathrm{mg} F A / \mathrm{L})$ and ammonium oxidation $(10-150 \mathrm{mg}$ $\mathrm{FA} / \mathrm{L})$. At high $\mathrm{pH}(>8)$, free ammonia became the main inhibitor for nitrification, at low $\mathrm{pH}(<7.5)$ nitrous acid was the main inhibitor. Nitrification and denitrification efficiency was decreased with increasing influent $\mathrm{COD} / \mathrm{N}$ ratio as it was decreased the nitrification rate. Anammox denitrification dominated at $\mathrm{COD} / \mathrm{N}$ ratio of 0 but for $\mathrm{COD} / \mathrm{N}$ ratio equal or higher than 2, there was heterotrophic denitrification. Controlling of oxygen concentration and COD/N ratio would determine the efficiency of the nitrogen removal process.

\section{Acknowledgment}

Authors gratefully acknowledge the SUST Research Centre, SUST for financial support (Project ID: AS/2018/3/36).

\section{References}

1. X. Wang, R. Yang, Z. Zhang, J. Wu, and S. Chen, Bioresou. Technol. 292, 122005 (2019). https://doi.org/10.1016/j.biortech.2019.122005

2. G. Zhu, Y. Peng, B. Li, J. Guo, Q. Yang, and S. Wang, Rev. Environ. Contam. Toxicol. 192, 159 (2008). https://doi.org/10.1007/978-0-387-71724-1_5

3. A. G. Capodaglio, P. Hlavínek, and M. Raboni, A. Interdiscipl. J. App. Sci., 11, 250 (2016). https://doi.org/10.4136/ambi-agua. 1772

4. T. Kindaichi, S. Okabe, H. Satoh, and Y. Watanabe, Water Sci. Technol. 49, 61 (2004). https://doi.org/10.2166/wst.2004.0805

5. U. Wiesmann, Biological Nitrogen Removal from Wastewater. In: Biotechnics/Wastewater. Advances in Biochemical Engineering/Biotechnology (Springer, Berlin, Heidelberg, 1994) vol 51 
6. X. Zheng, S. Zhang, J. Zhang, D. Huang, and Z. Zheng, Water Sci. Technol. 77, 2723 (2018). https://doi.org/10.2166/wst.2018.231

7. M. Chaali, M. Naghdi, S.K. Brar, and A. Avalos-Ramirez, Chem. Technol. Biotechnol. 93, 3113 (2018). https://doi.org/10.1002/jctb.5692

8. B. Baumann, M. Snozzi, J. R. van der Meer, and A. J. B. Zehnder, Water Res. 31, 1947 (1996). https://doi.org/10.1016/S0043-1354(97)00053-5

9. K. M. Udert, E. Kind, M. Teunissen, S. Jenni, and T. A. Larsen, Water Sci. Technol. 58, 277 (2008). https://doi.org/10.2166/wst.2008.389

10. Metcalf and Eddy, Revised by G. Tchobananoglous, and F. L. Burton, Wastewater Engineering: Treatment, Disposal and Reuse (McGraw-Hill, New York, 2003).

11. H. Siegrist, Water Sci. Technol. 34, 399 (1996). https://doi.org/10.2166/wst.1996.0397

12. N. Chamchoi, S. Nitisoravut, and J. E. Schmidt, Bioresou. Technol. 99, 3331 (2008). https://doi.org/10.1016/j.biortech.2007.08.029

13. C. Tang, P. Zheng, C. Wang, and Q. Mahmood, Bioresou. Technol. 101, 1762 (2010). https://doi.org/10.1016/j.biortech.2009.10.032

14. M. Strous, J. A. Fuerst, E. H. M. Kramer, S. Logemann, G. Muyzer, and K. T. van de PasSchoonen, Nature 400, 446 (1999). https://doi.org/10.1038/22749

15. Y. Tal, J. E. M. Watts, and H. J. Schreier, Appl. Environ. Microbiol. 72, 2896 (2006). https://doi.org/10.1128/AEM.72.4.2896-2904.2006

16. M. S. M Jetten, M. Strous, K. T. van de Pas-Schoonen, J. Schalk van, U. G. J. M. van Dongen, A. A. van de Graaf, S. Logemann, G. Muyzer, M. C. M. van Loosdrecht, and J. G. Kuenen, FEMS Microbiol. 22, 421 (1999). https://doi.org/10.1111/j.1574-6976.1998.tb00379.x

17. M. Strous, E. Pelletier, S. Mangenot, T. Rattei, A. Lehner, M. W. Taylor, M. Horn, H. Daims, D. Bartol-Mavel, P. Wincker, V. Barbe, N. Fonknechten, D. Vallenet, B. Segurens, C. Schenowitz-Truong, C. Medigue, A. Collingro, B. Snel, B. E. Dutilh, H. J. Op den Camp, C. van der Drift, I. Cirpus, K. T. van de Pas-Schoonen, H. R. Harhangi, L. van Niftrik, M. Schmid, J. Keltjens, J. van de Vossenberg, B. Kartal, H. Meier, D. Frishman, M. A. Huynen, H. W. Mewes, J. Weissenbach, M. S. Jetten, M. Wagner, and D. Le Paslier, Nature 440, 790 (2006). https://doi.org/10.1038/nature04647

18. A. A. Van de Graaf, P. de Bruijn, L. A. Robertson, M. S. M. Jetten, and J. G. Kuenen, Microbiology-UK, 143, 2415 (1997). https://doi.org/10.1099/00221287-143-7-2415

19. J. Schalk, Ph.D. Thesis, Delft University of Technology, Netherlands, 2000.

20. M. Schmid, U. Twachtmann, M. Klein, M. Strous, S. Juretschko, and M. S. M. Jetten, Syst. Appl. Microbiol. 23, 93 (2000). https://doi.org/10.1016/S0723-2020(00)80050-8

21. K. Egli, U. Fanger, P. J. J. Alvarez, H. Siegrist, J. R. Van Der Meer, and A. J. B. Ehnder, Arch. Microbiol. 175, 198 (2001). https://doi.org/10.1007/s002030100255

22. M. M. Jensen, M. M. M. Kuypers, G. Lavik, and B. Thamdrup, Limnol. Oceanogr. 53, 23 (2008). https://doi.org/10.4319/lo.2008.53.1.0023

23. A. Dapena-Mora, I. Fernandez, J. L. Campos, A. Mosquera-Corral, R. Mendez, and M. S. M. Jetten, Enzyme Microbiol. Tech. 40, 859 (2007). https://doi.org/10.1016/j.enzmictec.2006.06.018

24. A. O. Sliekers, N. Derwort, J. L. Gomez, M. Strous, J. G. Kuenen, and M. S. M. Jetten, Water Res. 36, 2475 (2002).

25. J. Li, J. Li, R. Gao, M. Wang, L. Yang, X. Wang, L. Zhang, and Y. Peng, Bioresou. Technol. 265, 498 (2018). https://doi.org/10.1016/j.biortech.2018.07.013

26. Y. J. Feng, S. K. Tseng, T. H. Hsia, C. Ho, and W. Chou, J. Biosci. Bioeng. 104, 182 (2007). https://doi.org/10.1263/jbb.104.182

27. X. D. Hao and M. C. van Loosdrecht, Water Sci. Technol. 49, 83 (2004). https://doi.org/10.2166/wst.2004.0810

28. A. O. Sliekers, K. A. Third, and W. Abma, FEMS Microbiol. Lett. 218, 339 (2003). https://doi.org/10.1016/S0378-1097(02)01177-1

29. Z. Gong, F. Yang, S. Liu, H. Bao, S. Hu, and K. Furukawa, Chemosphere 69, 776 (2007). https://doi.org/10.1016/j.chemosphere.2007.05.023 
30. M. Morita, N. Kudo, H. Uemoto, A. Watanabe, and H. Shinozaki, Eng. Life Sci. 7, 587 (2007). https://doi.org/10.1002/elsc.200700014

31. X. Zhang, J. Zhou, H. Guo, Y. Qu, G. Liu, and L. Zhao, Process Biochem. 42, 620 (2007). https://doi.org/10.1016/j.procbio.2006.11.012

32. E. Walters, A. Hille, M. He, C. Ochmann, and H. Horn, Water Res. 43, 4461 (2009). https://doi.org/10.1016/j.watres.2009.07.005

33. Y. Ma, Y. Peng, S. Wang, Z. Yuan, and X. Wang, Water Res. 43, 563 (2009). https://doi.org/10.1016/j.watres.2008.08.025

34. C. Fux, S. Velten, V. Carozzi, D. Solley, and J. Keller, Water Res. 40, 2765 (2006). https://doi.org/10.1016/j.watres.2006.05.003

35. K. Hibiya, A. Terada, S. Tsuneda, and A. Hirata, J. Biotechnol. 100, 23 (2003). https://doi.org/10.1016/S0168-1656(02)00227-4

36. H. Uemoto and H. Saiki, Biotechnol. Bioeng. 67, 80 (2000). https://doi.org/10.1002/(SICI)1097-0290(20000105)67:1<80::AID-BIT9>3.0.CO;2-E

37. M. Morita, H. Uemoto, and A. Watanabe, Biochem. Eng. J. 41, 59 (2008). https://doi.org/10.1016/j.bej.2008.03.008

38. B. E. Rittmann and W. E. Langeland, J. WPCF 57, 300 (1985). https://doi.org/10.2307/20635339

39. K. Pochana, J. Keller, and P. Lant, Water Sci. Technol. 39, 235 (1999). https://doi.org/10.2166/wst.1999.0050

40. K. Pochana and J. Keller, Water Sci. Technol. 39, 61 (1999). https://doi.org/10.2166/wst.1999.0262

41. E. Gogina and I. Gulshin, Procedia Eng. 153, 189 (2016). https://doi.org/10.1016/j.proeng.2016.08.101

42. U. Abeling and C. F. Seyfried, Water Sci. Technol. 26, 1007 (1992). https://doi.org/10.2166/wst.1992.0542

43. M. Beccari, A. C. Dipinto, R. Ramadori and M. C. Tomei, Water Res. 26, 1099 (1992). https://doi.org/10.1016/0043-1354(92)90146-U

44. S. Philips, H. J. Laanbroek, and W. Verstraete, Rev. Environ. Sci. Biotechnol. 1, 115 (2002). https://doi.org/10.1023/A:1020892826575

45. J. H. Hunik, J. Tramper, and R. H. Wijffels, Bioprocess Eng. 11, 73 (1994). https://doi.org/10.1007/BF00389563

46. D. Barnes and P. J. Bliss, Biological Control of Nitrogen in Wastewater Treatment (E. \& F. N. Spon, London, 1983).

47. R. Manser, W. Gujer, and H. Siegrist, Water Res. 39, 4633 (2005). https://doi.org/10.1016/j.watres.2005.09.020

48. H. Yoo, K. H. Ahn, K. H. Lee, Y. U. Kwak, and K. G. Song, Water Res. 33, 145 (1999). https://doi.org/10.1016/S0043-1354(98)00159-6

49. M. Laureni, D. G. Weissbrodt, K. Villez, O. Robin, N. de Jonge, A. Rosenthal, G. Wells, J. L. Nielsen, E. Morgenroth, and A. Joss, Water Resou. 154, 104 (2019). https://doi.org/10.1016/j.watres.2018.12.051

50. S. W. H. Van Hulle, E. I. P. Volcke, T. J. López, B. Donckels, M. C. M. van Loosdrecht, and P. A. Vanrolleghem, J. Chem. Technol. Biotechnol. 82, 471 (2007). https://doi.org/10.1002/jetb.1692

51. M. Brouwer, M. C. M. van Loosdrecht, and J. J. Heijnen, One Reactor System for Ammonium Removal via Nitrite (STOWA report, STOWA, Utrecht, 1996).

52. W. Zeng, Y. Z. Peng, S. Y. Wang, and C. Y. Peng, Chem. Eng. Technol. 31, 582 (2008). https://doi.org/10.1002/ceat.200700468

53. Q. Yao and D. C. Peng, AMB Express 7, 1 (2017). https://doi.org/10.1186/s13568-017-0328-y

54. M. S. I. Mozumder, C. Picioreanu, M. C. M. van Loosdrecht, and E. I. P. Volcke, Environ. Technol. 35, 1027 (2014). https://doi.org/10.1080/09593330.2013.859711

55. G. Cema, J. Wiszniowski, S. Zabczynski, E. Zabłocka-Godlewska, A. Raszka, and J. SurmaczGorska, Water Sci. Technol. 55, 35 (2007). https://doi.org/10.2166/wst.2007.239 
56. S. Rysgaard, R. N. Glud, N. Risgaard-Petersen, and T. Dalsgaard, Limnol. Oceanogr. 49, 1493 (2004). https://doi.org/10.4319/lo.2004.49.5.1493

57. J. Dosta, I. Fernandez, J. R. Vazquez-Padin, A. Mosquera-Corral, J. L. Campos, J. Mata-Alvarez, and R. Mendez, J. Hazard. Mater. 154, 688 (2008). https://doi.org/10.1016/j.jhazmat.2007.10.082

58. U. Welander and B. Mattiasson, Water Resou. 37, 2394 (2003). https://doi.org/10.1016/S00431354(03)00019-8

59. S. W. H. Van Hulle, H. J. P. Vandeweyer, B. D. Meesschaert, P. A. Vanrolleghem, P. Dejans, and A. Dumoulin, Chem. Eng. J. 162, 1 (2010). https://doi.org/10.1016/j.cej.2010.05.037

60. C. Hellinga, A. Schellen, J. W. Mulder, M. C. M. van Loosdrecht, and J. J. Heijnen, Water Sci. Technol. 37, 135 (1998). https://doi.org/10.2166/wst.1998.0350

61. N. C. Brady and R. R. Weil, The Nature and Properties of Soils, $13^{\text {th }}$ Edition (Prentice Hall, New Jersey, 2003).

62. C. Trouve, P. M. Chazal, B. Gueroux, and N. Sauvaitre, Environ. Technol. 19, 601 (1998). https://doi.org/10.1080/09593331908616716

63. K. Lee and B. Rittmann, Water Resou. 37, 1551 (2003). https://doi.org/10.1016/S0043-1354(02)00519-5

64. A. C. Anthonisen, R. C. Loehr, T. B. S. Prakasam, and E. G. Srinath, J. Water Pollut. Control. Fed. 48, 835 (1976).

65. Y. Jung, S. H. Kang, and Y. C. Chung, Water Sci. Technol. 55, 459 (2007). https://doi.org/10.2166/wst.2007.023

66. W. Bae, S. Baek, J. Chung, and Y. Lee, Biodegradation 12, 359 (2001). https://doi.org/10.1023/A:1014308229656

67. J. M. Bremner and A. M. Blackmer, Science 199, 2951978. https://doi.org/10.1126/science.199.4326.295

68. J. Meiklejohn, Nature 170, 1131 (1952). https://doi.org/10.1038/1701131a0

69. H. Lees, Biochem. 42, 528 (1948). https://doi.org/10.1042/bj0420528

70. D. Guocheng, J. Gang, J. Chen, and S. Lun, World J. Microbiol. Biotechnol. 19, 433 (2003). https://doi.org/10.1023/A:1023985229493

71. J. Li, L. Feng, B. K. Biswal, G. H. Chen, and D. Wu, Bioresou. Technol. 295, ID 122292 (2020). https://doi.org/10.1016/j.biortech.2019.122292

72. S. Lackner, A. Terada, and B. F. Smets, Water Res. 42, 1102 (2008). https://doi.org/10.1016/j.watres.2007.08.025

73. S. Matsumoto, M. Katoku, G. Saeki, A. Terada, Y. Aoi, S. Tsuneda, C. Picioreanu, and M. C. M. van Loosdrecht, Environ. Microbiol. 12, 192 (2010). https://doi.org/10.1111/j.1462-2920.2009.02060.x

74. M. S. Moussa, C. M. Hooijmans, H. J. Lubberding, H. J. Gijzen, and M. C. M. van Loosdrecht, Water Res. 39, 5080 (2005). https://doi.org/10.1016/j.watres.2005.09.038

75. S. F. Yang, J. H. Tay, and Y. Liu, Current Microbiol. 49, 42 (2004).

76. J. Carrera, T. Vicent, and J. Lafuente, Process Biochem. 39, 2035 (2004). https://doi.org/10.1016/j.procbio.2003.10.005

77. B. E. Rittmann, C. S. Laspidou, J. Flax, D. A. Stahl, V. Urbain, H. Harduin, J. J. van der Waarde, B. Geurkkink, M. J. C. Henssen, H. Brouwer, A. Klapwijk, and M. Wetterauw, Water Sci. Technol. 39, 51 (1999). https://doi.org/10.2166/wst.1999.0012

78. P. Harremoes and O. Sinkjaer, Water Res. 29, 899 (1995). https://doi.org/10.1016/0043-1354(94)00207-N

79. Y. L. Hsieh, S. K. Tseng, and Y. J. Chang, Bioresou. Technol. 88, 107 (2003). https://doi.org/10.1016/S0960-8524(02)00274-2

80. J. Vrtovsek and M. Ros, Acta Chimica Slovenica 53, 396 (2006).

81. H. Satoh, H. Ono, B. Rulin, J. Kamo, S. Okabe, and K. Fukushi, Water Res. 38, 1633 (2004). https://doi.org/10.1016/j.watres.2003.12.020

82. H. Liu, F. Yang, S. Shi, and X. Liu, J. Environ. Sci. 22, 540 (2010). https://doi.org/10.1016/S1001-0742(09)60143-1 
774 Review Article: Biological Nitrogen Removal Processes and Operating Parameters

83. K. Deng, L. Tang, J. Li, J. Meng, and J. Li, Bioresou. Technol. 294, ID 122193 (2019). https://doi.org/10.1016/j.biortech.2019.122193

84. X. Li, J. Zhang, X. Zhang, J. Li, F. Liu, and Y. Chen, Process Biochem. 84, 134 (2019). https://doi.org/10.1016/j.procbio.2019.06.010 